\title{
Residual Effect of Integrated Nutrient Management on Yield and Nutrients Uptake of Wheat under Rice-Wheat System
}

\author{
Sunil Kumar ${ }^{1}$, Sanjay Tiwari², Birendra Kumar ${ }^{3}$, B. K. Vimal ${ }^{1}$, \\ R. D. Ranjan ${ }^{4 *}$ and C.S. Azad ${ }^{5}$ \\ ${ }^{1}$ Department of Soil Science and Agricultural Chemistry, ${ }^{3}$ Department of Agronomy, \\ ${ }^{4}$ Department of Plant Breeding and Genetics, ${ }^{5}$ Department of Plant Pathology, Bihar \\ Agricultural University, Sabour, Bhagalpur, (Bihar) - 813210, India \\ ${ }^{2}$ Department of Soil Science, Rajendra Agricultural University, Pusa, Samastipur, (Bihar)- \\ 848125, India \\ *Corresponding author
}

\section{A B S T R A C T}

\section{Keywords}

FYM, Green manure, Grain yield, INM, Nutrient uptake, Wheat

\section{Article Info}

Accepted: 07 August 2020 Available Online: 10 September 2020
A field experiment was conducted during kharif season at Rajendra Agricultural University, Pusa to assess the residual impact of conjoint use of organics and chemical fertilizers on yield and nutrients uptake of wheat under rice-wheat system. Results revealed that among the organics, FYM $10 \mathrm{t} \mathrm{ha}^{-1}$ application, produced highest grain yield (36.38 q ha ${ }^{-1}$ ) followed by Straw (32.84 q ha ${ }^{-1}$ ), Dhaincha (GM) (28.93q ha ${ }^{-1}$ ) and Urd $\left(27.61 \mathrm{q} \mathrm{ha}^{-1}\right)$. Increasing levels of inorganic fertilizers also increased the wheat grain and straw yield with the maximum grain $\left(36.34 \mathrm{q} \mathrm{ha}^{-1}\right)$ and straw $\left(51.95 \mathrm{q} \mathrm{ha}^{-1}\right)$ yield was observed in $100 \%$ recommended NPK treatment. Among all the treatments, highest grain yield $\left(41.67 \mathrm{q} \mathrm{ha}^{-1}\right)$ and uptake of major nutrients i.e. $\mathrm{N}\left(108.37 \mathrm{~kg} \mathrm{ha}^{-1}\right), \mathrm{P}\left(25.45 \mathrm{~kg} \mathrm{ha}^{-1}\right)$ and $\mathrm{K}\left(99.03 \mathrm{~kg} \mathrm{ha}^{-1}\right)$ in wheat were observed under combined application of $100 \% \mathrm{NPK}+$ FYM. Besides this, the fertilizer use efficiency (FUE) for N, P and K was found maximum in the treatment replacing $50 \%$ of $\mathrm{N}$ through FYM $+50 \%$ NPK. Thus, higher yield at balanced nutrition is safe guard for soil fertility and integrated plant nutrient supply system could help in meeting the goals of balanced fertilization as well as ita reliable way for obtaining fairly high productivity with increased FUE and an alternative practice towards sustainable agriculture.

\section{Introduction}

Among the cereals, rice and wheat are the world's most important staple food crops and are generally grown in sequence in the South Asia occupying an area of about 13.5 million ha of prime agricultural land in Bangladesh, India, Nepal, and Pakistan, with another 12 million ha in China (Ladha et al., 2000). In India alone, the system occupies about 10.0 million ha in the Indo-Gangetic plains (IGP) mostly located in UP (4.8 m ha), Punjab (1.5 $\mathrm{m} \mathrm{ha})$, Bihar (1.6 m ha), MP (1.3 m ha) and Haryana (0.5 m ha) (Singh et al., 1994; Modgal et al., 1995; Ladha et al., 2005) and provides food security for 400 million of 
people (Ladha et al., 2000). At global level, India ranks as second largest wheat producing nation and contributing approximately $11.9 \%$ to the world wheat production from about $12 \%$ of global area (USDA, 2010). The area under wheat throughout the world as well as in India has become nearly constant around 217.9 million ha and 26.9 million ha respectively. Wheat contributes about $30 \%$ of total grain production in India. Long time studies being carried out at several locations in India indicated that application of all the needy nutrients through chemical fertilizers have deterious effect on soil health leading to unsustainable yields. Looking at the actual scenario in the northern alluvial belt, it seems that available resources and input use may account for higher productivity in Punjab and poor yields in Bihar (Modgal et al., 1995).

These variations in productivity may be due to variations in the agro-ecological conditions, degree of water control, levels of inputs used and farmers' skill. This system is primarily dependent on inorganic fertilizers only. Deficit in availability of fertilizer nutrients is one problem and declining tendency in rice-wheat productivity due to continuous use of only inorganic fertilizers in the system is the other (Ladha et al., 2005; Rahman et al., 2009). In order to make the soil well supplied with all the plant nutrients in the readily available form and to maintain good soil health, it is necessary to use organic manures in conjunction with inorganic fertilizers to obtain optimum yields. The ricewheat cropping system needs higher inputs and the declining trends in system's productivity due to depletion of organic matter in the soil, which results disturbance in soil aggregation, soil productivity and soil health (Abrol and Gill, 1994; Modgal et al., 1995; Patro et al., 2011) need to be taken care of prudently. Since the farmers of the region are resource poor, therefore, there is a need for complete or partial substitution of inorganic fertilizers, by locally available organic sources for sustaining rice production (Acharya and Mandal, 2010; Brahmachari et al., 2011).

Therefore, there is a need to improve nutrient supply system in terms of integrated nutrient management involving the use of chemical fertilizers in conjunction with organic manures coupled with input through biological processes (Prasad et al., 1995; Aulakh, 2010). Moreover, application of imbalanced nutrients could lead to declining nutrient-use efficiency making fertilizer consumption uneconomical and adversely affecting the atmosphere (Aulakh and Adhya, 2005) and groundwater quality (Aulakh et al., 2009) causing health hazards and climate change. Under such a condition, there is need to explore the possibilities of using the expanding native sources of plant nutrient.

The organic sources of nutrients like dhaincha, rice straw and green legumes (Dixit and Gupta, 2000) and organic manure such as FYM (Kumari et al., 2010) are gaining global importance for rice-wheat system. In this context, the present study was undertaken to study the effect of integrated supply of inorganic fertilizers along with some organic sources of nutrients on yield, nutrients uptake by wheat under intensively cultivated ricewheat cropping systems.

\section{Materials and Methods}

\section{Site description}

The field experiment was conducted with test crop wheat in rice-wheat copping system on an Inceptisols at North Chhawania of Rajendra Agricultural University, Pusa, Bihar,

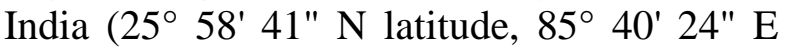
longitude and $52.4 \mathrm{~m}$ above mean sea level). The climate is hot, humid subtropics with an average annual rainfall of approximately 1380 $\mathrm{mm}$ and mean annual minimum and maximum temperatures of 13.5 and $38.2^{\circ} \mathrm{C}$, 
respectively. The soil is hyperthermic (AericHaplaquept) according to US Soil Taxonomy, Soil Survey Staff (2003) and sandy loam in texture. The $\mathrm{pH}$ of the soil at the start of experiment was neutral $(\mathrm{pH} \mathrm{8.5)}$ in reaction with sand, silt, and clay values of $57.76,28.23$ and $14.01 \%$, respectively.

The oxidizable organic $\mathrm{C}$, available $\mathrm{N}, \mathrm{P}$ and $\mathrm{K}$ content of the soil $(0-0.2 \mathrm{~m})$ are $5.1 \mathrm{~g} \mathrm{~kg}^{-1}$, $200.32 \mathrm{~kg} \mathrm{ha}^{-1}, 14.46 \mathrm{~kg} \mathrm{ha}^{-1}$ and $96.18 \mathrm{~kg}$ $\mathrm{ha}^{-1}$, respectively. The bulk density and cation exchange capacity values of the initial soil were $1.35 \mathrm{Mg} \mathrm{m}^{-3}$ and $31.0 \mathrm{Cmol}(\mathrm{p}+) \mathrm{kg}^{-1}$, respectively.

\section{Description of field experiment}

Wheat was grown under irrigated condition following the standard package of practices. The popularly grown wheat cultivar $H U W$ 206was used for the experiment. The experimental plot was well drained and had uniform topography with assured tube well irrigation facility.

The experiment was laid out in a split plot design with five main plot treatments and five sub-plot treatments in three replications.

The organic sources of nutrients are used in main plots in kharif before rice transplanting, while inorganic sources of nutrients were used in sub plot treatments.

The details of main plot treatments were $\mathrm{M}_{1}$ green manure [dhaincha (Sesbania rostrata)], $\mathrm{M}_{2}$ - green legume [urd (Vigna mungo)], $\mathrm{M}_{3}$ -FYM@10 t ha ${ }^{-1}, \mathrm{M}_{4}$ - straw @ $5 \mathrm{tha}^{-1}$ and $\mathrm{M}_{5}$ - weedy fallow, whereas, the details of sub-plot treatments were $\mathrm{S}_{1}-$ Control, $\mathrm{S}_{2}-$ $50 \% \mathrm{PK}, \mathrm{S}_{3}-50 \% \mathrm{NPK}, \mathrm{S}_{4}-100 \% \mathrm{PK}$ and $\mathrm{S}_{5}-100 \%$ NPK. The recommended dose of NPK was $120 \mathrm{~kg} \mathrm{~N}, 60 \mathrm{~kg} \mathrm{P}_{2} \mathrm{O}_{5}$ and $40 \mathrm{~kg}$ $\mathrm{K}_{2} \mathrm{O}$ per hectare.

\section{Analytical procedure}

Grain and straw yield of wheat were recorded from a harvest area of $10 \mathrm{~m}^{2}$. Plant samples were first washed with running tap water followed by washing with $0.01 \mathrm{~N} \mathrm{HCl}$ and finally with double distilled water. After that, plant samples were dried in a hot air oven at $50^{\circ} \mathrm{C}$ for 48 hours till the constant weight was achieved.

After drying, the samples were ground to fine powder by using stainless steel grinder for further analysis. Total $\mathrm{N}$ content of the plant samples as well as organic materials were analyzed by Kjeldahl method using Kel-Plus analyzer (Pelican Equipments, Chennai, India), while total $\mathrm{P}$ and $\mathrm{K}$ content of the plant samples were analyzed in aqueous extracts prepared after wet-digestion with a di-acid mixture of $\mathrm{HNO}_{3}$ and $\mathrm{HClO}_{4}$ (9:4 ratio) using UV-Visible spectrophotometer (Systronics 118) and Flame photometer (Systronics 128), respectively (Jackson, 1973).

\section{Statistical analysis}

The analysis of variance (ANOVA) of the measured parameters was performed by windows based Statistical Package namely SPSS (ver. 9.3) and the least significant difference (LSD) test was applied to evaluate the significance of the differences between the variables and treatments.

\section{Results and Discussion}

The different organic and inorganic treatment applied in rice were evaluated for their residual effect on wheat crop at normal doses of NPK (120:60:40kg/ha N, $\mathrm{P}_{2} \mathrm{O}_{5}$ and $\mathrm{K}_{2} \mathrm{O}$ ) fertilizers uniformly applied in $r a b i$ season. 


\section{Wheat crop yield}

\section{Grain yield}

A perusal of the data in table 1 indicated that the grain of wheat ranged from 19.31 to 41.67 $\mathrm{q} / \mathrm{ha}$ as influenced by different treatment combinations. The highest grain of wheat $36.38 \mathrm{q} / \mathrm{ha}$ was recorded in FYM treatment and was superior over straw (32.84 q/ha), dhaincha (GM) (28.93 q/ha), urd (GL) $(27.61 \mathrm{q} / \mathrm{ha})$ and weedy fallow (23.58 q/ ha). The residual effect of dhaincha $(28.93 \mathrm{q} / \mathrm{ha})$ and urd $(27.61 \mathrm{q} / \mathrm{ha})$ were statistically at par with each other. From these observations, it may be inferred that manures applied to the previous crop cold definitely display a significant positive role on the succeeding wheat crop. Many long term experiments suggested the advantageous effect of continuous manuring and rotational practices on maintaining soil fertility and sustaining crop productivity. The same case was found true in the present investigation which showed the residual and cumulative effects of organic manures and inorganic fertilizers on the yield of wheat crop. Similar findings were also reported by Gaur et al., (1984) and Rai et al., (1990). The more prominent role of FYM was ascribed due to more addition of organic nutrients which exhibited the higher residual values as results of slow mineralization. It is beneficial not only in enhancing the yield of rice but also promoting the wheat yield to a little extent and improving the overall productivity of the soil (Tiwari and Pathak, 1979).Inorganic fertilizer given directly to wheat crop showed highly significant influence on grain yield of wheat. The decreasing trend of grain yield of wheat was observed in the order of $36.94 \mathrm{q} / \mathrm{ha}(100 \%$ NPK) $>32.05 \mathrm{q} / \mathrm{ha}(50 \% \mathrm{NPK})>29.94 \mathrm{q} / \mathrm{ha}$ $(100 \%$ PK $)>26.12$ q/ha $(50 \%$ PK $)>24.89$ $\mathrm{q} / \mathrm{ha}$ (control).However, the interactive residual effect of organic sources in conjunction with fertilizers on grain yield of wheat was found non-significant. Even though the additional; residual advantage in using FYM and straw with chemical fertilizers was apparent as also shown by the higher grain yield recorded in FYM treatment with all the levels of chemical fertilizers. Similar results were also reported by Mandal and Mandal (1990). They observed that irrespective of the nutrients level, combined application of FYM and NPK produced significantly higher yield than NPK alone. In another experiment in china (Li et al., 2010) concluded that INM was the most suitable approach for profitable crop production in sustained manner.

\section{Straw yield}

Similar to grain yield presented in table 1 the stare yield of wheat varied from 26.16 to $61.76 \mathrm{q} / \mathrm{ha}$ due to the impact of various treatment combinations. The maximum straw yield (48.16 q/ha) was recorded with FYM treatment which was followed by straw (42.13 q/ha), dhaincha (GM) (39.39 q/ha) and weed fallow (31.69 q/ha) treatment. However, the residual effect of organic sources as shown by dhaincha (GM) (39.39 q/ha) and urd (GL) (38.18 q/ha) treatments was statistically at par with each other. The effect of all organic sources on straw yield of wheat can be shown in following order as: FYM > straw > dhaincha $=$ urd $>$ weedy fallow combinations. These results further indicated that about 25-30 per cent of $\mathrm{N}$ content in FYM could be absorbed by rice plant during the first croup. Consequently, accumulated $\mathrm{N}$ and other nutrients in soil were gradually mineralized and utilized by successive crop (Gaur et al., 1984). The results showing effect of NPK fertilizer applied tow heat crop indicated that the maximum straw yield $(51.95 \mathrm{q} / \mathrm{ha})$ with $100 \%$ NPK was achieved and followed by $50 \%$ NPK (43.26 q/ha) with 100\% PK (39.60 q/ha), 50\% PK (32.84 q/ha) and control $(31.91 \mathrm{q} / \mathrm{ha})$ treatment. Contrary 
to the results obtained in grain yield here interactive residual effect of organic sources and inorganic fertilizers were found to be significant. The higher straw yield (61.76 q/ha) was recorded in FYM with 100\% NPK treatment combinations while, minimum $(25.16 \mathrm{q} / \mathrm{ha})$ was recorded in weedy fallow with control treatment combination. However, the straw yield in FYM and straw combination with all NPK levels differed statistically to each other except with 100\% PK treatment combination. It was also observed that dhiancha and urd treatment gave statistically similar yield at all the levels of inorganic fertilizers combinations except $100 \%$ NPK. Similar results were also observed by Meelu and Rekhi (1981) \& Sharma and Mitra (1990).

Table.1 Influence of organic and inorganic fertilizers on the yield of wheat in rice - wheat system

\begin{tabular}{|c|c|c|c|c|c|c|c|c|c|c|c|c|}
\hline \multirow{3}{*}{$\begin{array}{l}\text { Inorganic } \\
\text { fertilizer } \\
\text { levels }\end{array}$} & \multicolumn{6}{|c|}{ Grain yield (q/ha) } & \multicolumn{6}{|c|}{ Straw yield (q/ha) } \\
\hline & \multicolumn{6}{|c|}{ Organic source } & \multicolumn{6}{|c|}{ Organic sources } \\
\hline & $\begin{array}{c}\text { Dhaincha } \\
\text { (GM) }\end{array}$ & $\begin{array}{l}\text { Urd } \\
\text { (GL) }\end{array}$ & FYM & Straw & $\begin{array}{l}\text { Weedy } \\
\text { fallow }\end{array}$ & Mean & $\begin{array}{l}\text { Dhain } \\
\text { cha } \\
(\mathrm{GM})\end{array}$ & $\begin{array}{c}\text { Urd } \\
\text { (GL) }\end{array}$ & FYM & Straw & $\begin{array}{l}\text { Weedy } \\
\text { fallow }\end{array}$ & Mean \\
\hline Control & 24.08 & 22.08 & 31.65 & 27.32 & 19.31 & 24.89 & 30.26 & 29.14 & 42.25 & 32.74 & 25.16 & 31.96 \\
\hline $50 \%$ PK & 24.56 & 23.87 & 33.18 & 27.68 & 21.31 & 26.12 & 31.34 & 29.92 & 41.50 & 34.43 & 26.98 & 32.84 \\
\hline $50 \%$ NPK & 30.78 & 29.31 & 38.53 & 35.91 & 25.71 & 32.05 & 43.26 & 42.87 & 50.85 & 45.46 & 33.85 & 43.26 \\
\hline $100 \% \mathrm{PK}$ & 29.05 & 27.53 & 36.87 & 34.02 & 22.23 & 29.94 & 38.35 & 41.67 & 44.44 & 42.21 & 31.34 & 39.60 \\
\hline $100 \%$ NPK & 36.19 & 35.24 & 41.67 & 39.27 & 29.34 & 36.34 & 53.74 & 47.32 & 61.76 & 55.82 & 41.12 & 51.95 \\
\hline Mean & 28.93 & 27.61 & 36.38 & 32.84 & 23.58 & & 39.39 & 38.18 & 48.16 & 42.13 & 31.69 & \\
\hline \multirow{3}{*}{\multicolumn{2}{|c|}{$\begin{array}{l}\text { Sources } \\
\text { Organic manures }(M) \\
\text { Inorganic fertilizer }(\mathrm{S}) \\
\text { Interaction }(\mathbf{M} \times \mathbf{S})\end{array}$}} & \multirow{3}{*}{\multicolumn{2}{|c|}{$\begin{array}{c}\text { S.Em. } \\
0.43 \\
0.56 \\
1.21\end{array}$}} & \multirow{3}{*}{\multicolumn{2}{|c|}{$\begin{array}{c}\text { LSD }(\mathrm{P}<0.05) \\
1.40 \\
1.61 \\
\mathrm{NS}\end{array}$}} & & \multirow{3}{*}{\multicolumn{2}{|c|}{$\begin{array}{c}\text { S.Em. } \\
0.63 \\
0.61 \\
1.38\end{array}$}} & \multirow{3}{*}{\multicolumn{2}{|c|}{$\begin{array}{c}\mathrm{LSD}(\mathrm{P}<0.05) \\
2.04 \\
1.76 \\
4.06\end{array}$}} & & \\
\hline & & & & & & & & & & & & \\
\hline & & & & & & & & & & & & \\
\hline
\end{tabular}

Table.2 Influence of organic and inorganic fertilizers on the nitrogen uptake by wheat in of rice-wheat system

\begin{tabular}{|c|c|c|c|c|c|c|}
\hline \multirow{3}{*}{$\begin{array}{c}\text { Inorganic } \\
\text { fertilizer } \\
\text { levels }\end{array}$} & \multicolumn{6}{|c|}{ Total N- uptake (kg/ha) by wheat } \\
\hline & \multicolumn{6}{|c|}{ Organic sources } \\
\hline & $\begin{array}{c}\text { Dhaincha } \\
\text { (GM) }\end{array}$ & Urd (GL) & FYM & Straw & $\begin{array}{l}\text { Weedy } \\
\text { fallow }\end{array}$ & Mean \\
\hline Control & 46.82 & 43.15 & 66.78 & 50.93 & 32.47 & 48.03 \\
\hline 50\% PK & 49.29 & 46.51 & 70.99 & 52.67 & 35.53 & 51.00 \\
\hline $50 \%$ NPK & 68.05 & 63.14 & 88.28 & 72.61 & 47.06 & 67.83 \\
\hline $100 \%$ PK & 61.40 & 59.29 & 80.50 & 66.49 & 40.11 & 61.56 \\
\hline $100 \%$ NPK & 94.51 & 82.76 & 108.37 & 87.92 & 62.24 & 87.16 \\
\hline Mean & 64.01 & 58.97 & 82.98 & 66.13 & 43.48 & \\
\hline \multirow{4}{*}{\multicolumn{2}{|c|}{$\begin{array}{l}\text { Sources } \\
\text { Organic manures (m) } \\
\text { Inorganic fertilizer }(\mathbf{s}) \\
\text { Interaction }(\mathbf{m} \times \mathbf{~ s})\end{array}$}} & S.Em. \pm & \multicolumn{2}{|c|}{ LSD $(\mathrm{P}<0.05)$} & & \\
\hline & & 0.82 & 2.67 & & & \\
\hline & & 1.09 & 3.13 & & & \\
\hline & & 2.34 & NS & & & \\
\hline
\end{tabular}


Table.3 Influence of organic and inorganic fertilizers on phosphorous uptake by wheat in of rice-wheat system

\begin{tabular}{|c|c|c|c|c|c|c|}
\hline \multirow{3}{*}{$\begin{array}{c}\text { Inorganic } \\
\text { fertilizer } \\
\text { levels }\end{array}$} & \multicolumn{6}{|c|}{ Total P- uptake (kg/ha) by wheat } \\
\hline & \multicolumn{6}{|c|}{ Organic sources } \\
\hline & $\begin{array}{c}\text { Dhaincha } \\
\text { (GM) }\end{array}$ & Urd (GL) & FYM & Straw & $\begin{array}{l}\text { Weedy } \\
\text { fallow }\end{array}$ & Mean \\
\hline Control & 11.66 & 10.39 & 16.01 & 11.37 & 7.75 & 11.43 \\
\hline $50 \%$ PK & 12.79 & 11.72 & 16.95 & 12.58 & 9.40 & 12.69 \\
\hline $50 \%$ NPK & 16.06 & 15.56 & 20.45 & 17.31 & 11.77 & 16.34 \\
\hline $100 \% \mathrm{PK}$ & 15.23 & 15.01 & 19.19 & 16.19 & 10.63 & 15.34 \\
\hline $100 \%$ NPK & 21.37 & 19.29 & 25.45 & 21.38 & 14.84 & 21.78 \\
\hline Mean & 15.52 & 14.39 & 19.61 & 15.56 & 10.88 & \\
\hline \multirow{4}{*}{\multicolumn{2}{|c|}{$\begin{array}{l}\text { Sources } \\
\text { Organic manures (m) } \\
\text { Inorganic fertilizer }(\mathbf{s}) \\
\text { Interaction }(\mathbf{m} \times \mathbf{~ s )}\end{array}$}} & S.Em. \pm & \multirow{4}{*}{\multicolumn{2}{|c|}{$\begin{array}{c}\text { LSD }(\mathbf{P}<\mathbf{0 .} \\
1.21 \\
0.88 \\
\text { NS }\end{array}$}} & & \\
\hline & & 0.37 & & & & \\
\hline & & 0.31 & & & & \\
\hline & & 0.72 & & & & \\
\hline
\end{tabular}

Table.4 Influence of organic and inorganic fertilizers on potassium uptake by wheat in ricewheat system

\begin{tabular}{|c|c|c|c|c|c|c|}
\hline \multirow{3}{*}{$\begin{array}{c}\text { Inorganic } \\
\text { fertilizer } \\
\text { levels }\end{array}$} & \multicolumn{6}{|c|}{ Total K- uptake (kg/ha) by wheat } \\
\hline & \multicolumn{6}{|c|}{ Organic sources } \\
\hline & $\begin{array}{l}\text { Dhaincha } \\
\text { (GM) }\end{array}$ & Urd (GL) & FYM & Straw & $\begin{array}{l}\text { Weedy } \\
\text { fallow }\end{array}$ & Mean \\
\hline Control & 42.25 & 38.89 & 63.06 & 51.91 & 32.19 & 45.66 \\
\hline $50 \%$ PK & 48.78 & 44.86 & 68.35 & 57.41 & 35.86 & 51.05 \\
\hline $50 \%$ NPK & 66.64 & 61.97 & 83.98 & 75.57 & 48.23 & 67.27 \\
\hline $100 \% \mathrm{PK}$ & 60.18 & 62.58 & 75.46 & 71.19 & 44.58 & 62.80 \\
\hline $100 \%$ NPK & 84.22 & 75.51 & 99.03 & 91.34 & 63.36 & 82.89 \\
\hline Mean & 60.43 & 56.76 & 77.98 & 69.43 & 44.84 & \\
\hline \multirow{4}{*}{\multicolumn{2}{|c|}{$\begin{array}{l}\text { Sources } \\
\text { Organic manures (m) } \\
\text { Inorganic fertilizer (s) } \\
\text { Interaction (m x s) }\end{array}$}} & S.Em. \pm & \multirow{4}{*}{\multicolumn{2}{|c|}{$\begin{array}{c}\text { LSD }(\mathbf{P}<\mathbf{0} . \\
2.48 \\
2.40 \\
\text { NS }\end{array}$}} & & \\
\hline & & 0.76 & & & & \\
\hline & & 0.84 & & & & \\
\hline & & 1.84 & & & & \\
\hline
\end{tabular}


Fig.1 N, P and K uptake in wheat as influenced by organic manures

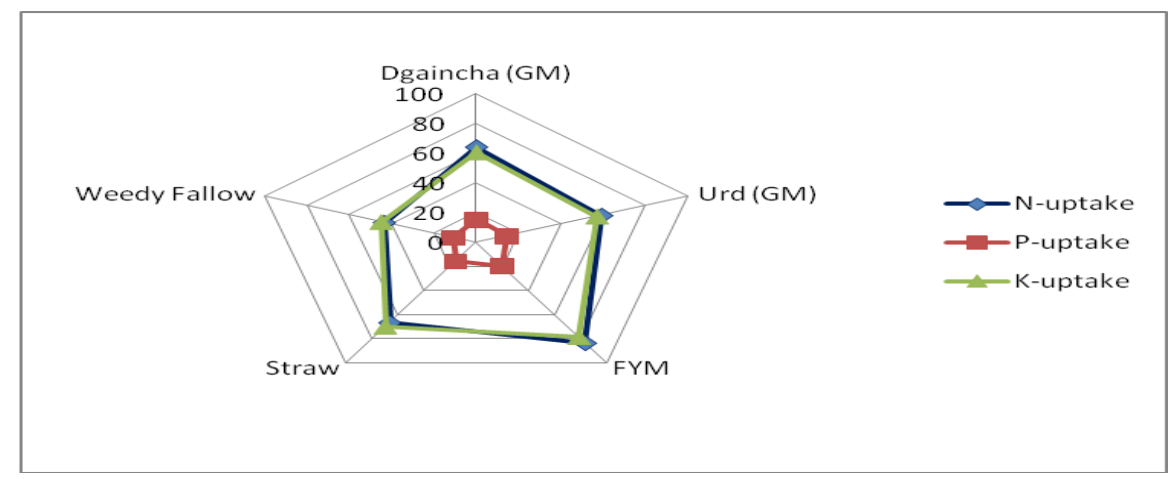

Fig.2 N, P and K uptake in wheat as influenced by inorganic fertilizers

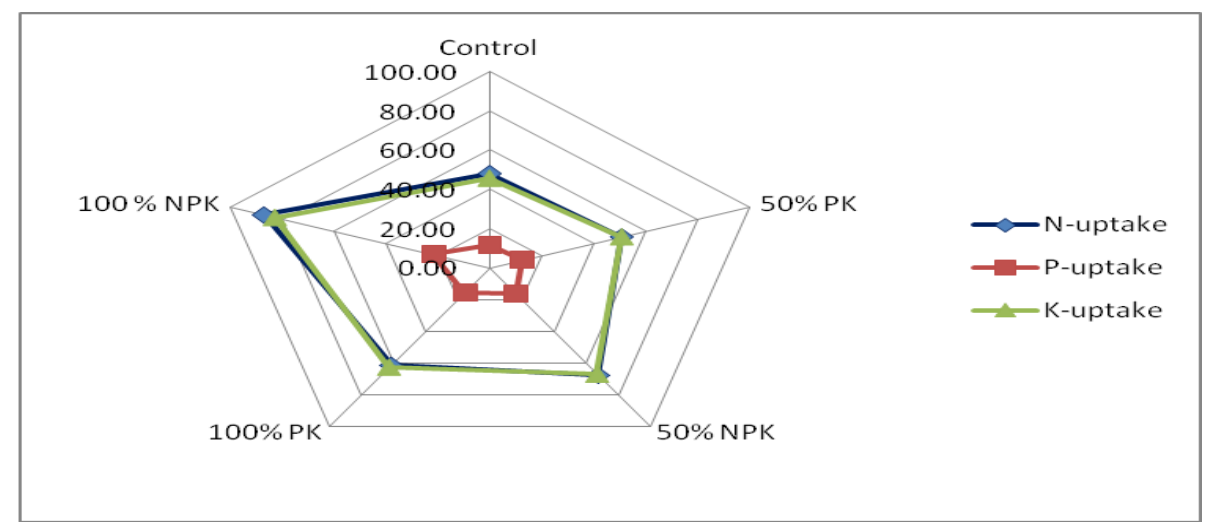

\section{Nutrient uptake in wheat}

\section{Total- N uptake}

The total $\mathrm{N}$ - uptake by wheat ranged from 32.47 to $108.37 \mathrm{~kg} / \mathrm{ha}$ as influenced by different treatment combinations. The results of total $\mathrm{N}$ - uptake in wheat are also presented in table 2 and figure $(1 \& 2)$ the data revealed that among the organic sources there were significant differences found in the total-N uptake by wheat crop. Higher N- uptake was recorded $(82.98 \mathrm{~kg} / \mathrm{ha})$ with FYM treatment, which showed significant superiority over straw (66.13 kg/ha), dhaincha (64.01 kg/ha), urd $(58.59 \mathrm{~kg} / \mathrm{ha})$ and weedy fallow $(43.48$ $\mathrm{kg} / \mathrm{ha}$ ) incorporations. The contribution of FYM and wheat straw increased the uptake of nitrogen (Sharma and Mitra, 1991).
The impact of different levels of NPK fertilization resulted in highly significant increase in total $\mathrm{N}$-uptake of wheat over control treatment. The highest total $\mathrm{N}$ - uptake $(87.16 \mathrm{~kg} / \mathrm{ha})$ was recorded with $100 \%$ NPK treatment which was followed by $50 \%$ NPK (67.83 kg/ha), 100\% PK (61.56 kg/ha), 50\% PK (51.00 kg/ha) and control (48.03 kg/ha) treatments. However, the interactions results due to the contribution of organic and inorganic did not show statistically significant. Nevertheless, the maximum total $\mathrm{N}$ - uptake was recorded as $108.37 \mathrm{~kg} / \mathrm{ha}$ under FYM and 100\% NPK treatment combination which was followed by dhaincha $(94.51 \mathrm{~kg} / \mathrm{ha})$, straw $(87.92 \mathrm{~kg} / \mathrm{ha})$, urd 82.76 $\mathrm{kg} / \mathrm{ha}$ and weedy fallow $(62.24 \mathrm{~kg} / \mathrm{ha})$ treatments as the same level of chemical fertilizers. Those results showed that the mineralization of residual FYM in wheat crop 
contributed the highest amount of $\mathrm{N}$ content in wheat grain. While, most of the parts of dhaincha (GM) and urd (GL) were already and quickly mineralised and taken by first rice crops. Sharma and Mitra, (1991) also reported that the decomposition process of organic sources which decreased the loss of applied nutrients and thus increased the release of nutrients to the plants.

\section{Phosphorus uptake}

\section{Total -P uptake}

Total $-\mathrm{p}$ uptake by wheat crop ranged from 7.75 to $25.45 \mathrm{kh} / \mathrm{ha}$ due to the influenced of various treatment combinations. Further the perusal of data in table 3 and figure $(1 \& 2)$ revealed that residual effect of organic sources significantly influenced the total phosphorus uptake in wheat. The total Puptake in weedy fallow $(10.88 \mathrm{~kg} / \mathrm{ha})$ was increased to $14.39 \mathrm{~kg} / \mathrm{ha}, 15.52 \mathrm{~kg} / \mathrm{h} a, 15.56$ $\mathrm{kg} / \mathrm{ha}$ and $19.61 \mathrm{~kg} / \mathrm{ha}$ due to residual effect if urd (GL) dhaincha (GM), straw and FYM incorporations, respectively. These data also indicated that total p- uptake with straw $(15.56 \mathrm{~kg} / \mathrm{ha})$, dhaincha $(15.52 \mathrm{~kg} / \mathrm{ha})$ and urd $(14.39 \mathrm{~kg} / \mathrm{ha})$ treatments were statistically similar. These results apparently showed that organics applied during the kharif season left a substantial quantity of nutrients even under high temperature, humid and tropical conditions which might be subsequently utilized by the succeeding rabi crop like wheat. It may also be possible that organic matter left in the soil might enhanced the uptake of applied as well as native nutrients by the crop through it influence on their availability in the soil (Rokima 1985).The residual impact of FYM, straw, dhaincha and urd incorporations on phosphorus by wheat grain might be due to the decomposition of these organics, which released more organic anions and hydroxyl acids. These acids helped in complexing or chelating $\mathrm{Fe}^{3+}, \mathrm{Al}^{3+}$ and
$\mathrm{Ca}^{2+}$ and preventing their reactions with phosphate ions to form in soluble phosphates and thus, more phosphorus might have available to the plants (Bindra and Thakur, 1996).

It was also obvious that maximum dose of NPK fertilizers resulted in highest removal of nutrients. It was also observed that there was an increase in total phosphorus uptake at $100 \%$ NPK, 50\%NPK $100 \%$ PK, 50\% PK levels over the control (11.43 kg/ha) as shown by total $\mathrm{p}$ - uptake values by wheat as 21.78 $\mathrm{kg} / \mathrm{ha}, 16.34 \mathrm{~kg} / \mathrm{ha}, 15.34 \mathrm{~kg} / \mathrm{ha}$ and 12.69 $\mathrm{kg} / \mathrm{ha}$, respectively. Thus these results emphasized that higher phosphorus uptake by wheat crop was recorded with higher fertility levels, which could sufficiently meet nutritional requirement of the corps as well as increasing NPK levels due to production of higher amount of biomass. These results are strictly in line with the findings of Dwivedi (1997). However, the interactive effects between organic sources and inorganic fertilizer were found to be statistically nonsignificant. Nevertheless, the highest total puptake $(25.45 \mathrm{~kg} / \mathrm{ha})$ by wheat crop was recorded under FYM and 100\% NPK treatment combination which was followed by straw $(21.38 \mathrm{~kg} / \mathrm{ha})$, dhaincha $(21.37 \mathrm{~kg} / \mathrm{ha})$, urd (19.29 kg/ha) and weedy fallow (14.84 $\mathrm{kg} / \mathrm{ha}$ ) with the same level of fertilizers combinations.

\section{Potassium uptake}

\section{Total - K uptake}

The inferences of the data estimated for total $\mathrm{k}$ - uptake in wheat crop revealed that it was significantly influenced by residual effects of different organic sources and chemical fertilizers. Total k-uptake varied from 32.19 to $99.03 \mathrm{~kg} / \mathrm{ha}$ in wheat crop (Table 4 and figure $1 \& 2$ ) the residual impact of various organic regarding the total potassium uptake 
by wheat crop might be shown in the following order. FYM $(77.98 \mathrm{~kg} / \mathrm{ha})>$ straw $(69.43 \mathrm{~kg} / \mathrm{ha})>$ dhaincha $(60.43)>$ urd 56.76 $\mathrm{kg} / \mathrm{ha}>$ weedy fallow (44.84 kg/ha). This trend was similar to the trend shown by grain and straw yield of wheat under the same treatment. Hence, higher yields under $100 \%$ NPK level of fertilizers along with organic sources were consequently accompanied with larger amount of nutrients removal by the crop. These results inferred that conjoint application of FYM, straw, dhaincha (GM) and urd (GL) and NPK fertilizers further increased the k-uptake as compared to the application of NPK alone. This might be due to the increased efficiency of the fertilizers in combination with organics as K-uptake is concerned. This also might be happened because of its effect on the formation of active and prolific roots resulting in increased absorption of nutrients. Besides this, significantly highest total k-uptake by wheat crop $(82.69 \mathrm{~kg} / \mathrm{ha})$ was recorded with $100 \%$ recommended NPK treatment. The trend of total k-uptake by wheat crop can be represented in the following order of superiority as: $100 \%$ NPK $(82.69 \mathrm{~kg} / \mathrm{ha})>$ $50 \%$ NPK $(67.27 \mathrm{~kg} / \mathrm{ha})>100 \%$ PK $(62.80$ $\mathrm{kg} / \mathrm{ha})>50 \%$ PK $(51.05 \mathrm{~kg} / \mathrm{ha})>$ control $(45.66 \mathrm{~kg} / \mathrm{ha})$ treatments. Further observations revealed that total uptake of potassium increased with progressive increase in the supply of NPK to the crop because of higher availability of these nutrients Santhy et al., (1998). However, interactions between residual effect of organic and inorganic sources on potassium uptake by wheat were did not turn out to be statistically significant

\section{References}

Abrol, I.P., and Gill, M.S. 1994. In: Regional office for Asia and Pacific (FAO) Publication. 11: 172-183.

Acharya, D., and Mandal, S.S. 2010. Effect of integrated nutrient management on the growth, productivity and quality of crops in rice (Oryza sativa L.) - cabbage (Brassica oleracea) - greengram (Vigna radiata) cropping system. Indian Journal of Agronomy, 55(1): 1-5.

Aulakh M.S., M.P.S. Khurana and Singh, D. 2009. Water pollution related to agricultural, industrial and urban activities, and its effects on food chain: Case studies from Punjab. Journal of New Seeds, 10: 112-137.

Aulakh, M.S., 2010. Integrated nutrient management for sustainable crop production, improving crop quality and soil health, and minimizing environmental pollution.19th World Congress of Soil Science, Soil Solutions for a Changing World, 1-6 August 2010, Brisbane, Australia.

Aulakh, M.S., and Adhya, T.K. 2005. Impact of agricultural activities on emission of greenhouse gases - Indian perspective. pp. 319-335. In: Proceedings of the International Conference on Soil, Water and Environmental Quality - Issues and Strategies, Indian Society of Soil Science, New Delhi.

Bindra, A.D. and Thakur R.C. (1996) Influence of green manures along with fertilizers on nitrogen, phosphorous and potassium content in rice. Oryza, 33: 143-145

Brahmachari, K., S.R. Choudhury, S. Karmakar, S. Dutta and Ghosh, P. 2011. Sustainable nutrient management in rice (Oryza sativa) - PairaChickling Pea (Lathyrus sativus) - Green Gram (Vigna radiata) sequence to improve total productivity of land under coastal zone of West Bengal. Rajshahi University Journal of Environmental Science, 1: 51-61.

Dixit, K.G., and Gupta, B.R. 2000.Effect of Farm yard manure, chemical and biofertilizers on yield and quality of rice and soil properties. Journal of the Indian 
Society of Soil Science, 48(4): 773-780.

Dwivedi, D.K., 1997. Integrated nutrient management for sustainable production under rice wheat cropping system. $\mathrm{Ph}$. D thesis in Agronomy, Rajendra Agricultural University, Pusa, Samastipur, Bihar, India.

Gaur, A C., Neelakantan, S. and Dargan, K S. (1984) Organic manures. Pub. And infor. Div., ICAR, New Delhi.

Jackson, M.L., 1973. Soil chemical analysis. New Delhi: Prentice Hall of India.

Kumari, N., A.K. Singh, S.K. Pal and Thakur, R. 2010. Effect of organic nutrient management on yield, nutrient uptake and nutrient balance sheet in scented rice (Oryza sativa). Indian Journal of Agronomy, 55(3): 220-223.

Ladha, J.K., Fischer, M. Hossain, P.R. Hobbs and Hardy, B. 2000.Improving the productivity and sustainability of ricewheat systems of the Indo-Gangetic Plains: A synthesis of NARS-IRRI partnership research. Disc. Paper No. 40. International Rice Research Institute, Philippines.

Ladha, J.K., H. Pathak, T.J. Krupnik, J. Six and Kessel, C.V. 2005. Efficiency of fertilizer nitrogen in cereal production: retrospect and prospects. Advances in Agronomy, 87: 85-156.

Li, Z., M. Liu, X. Wu, F. Han and Zhang, T. 2010. Effects of long-term chemical fertilization and organic amendments on dynamics of soil organic $\mathrm{C}$ and total $\mathrm{N}$ in paddy soil derived from barren land in subtropical China. Soil and Tillage Research, 106: 268-274.

Mandal, M.N. and Mandal, S.S. (1990).Effect of phosphorous, potassium and farm yard manure on growth and yield of wheat. Environment and Ecology, 8: 993-995

Meelu, O.P. and Rekhi, R. S. (1981) fertilizers use in rice based cropping system in northern India. Fert. News,
26: $16-22$.

Modgal, S.C., Y. Singh and Gupta, P.C. 1995. Nutrient management in rice-wheat cropping system. Fertilizer News, 40: 49-54.

Patro, H., D. Dash, D. Parida, P.K. Panda, A. Kumar, R.C. Tiwari and Shahid, M. 2011. Effect of organic and inorganic sources of nitrogen on yield attributes, grain yield and straw yield of rice (Oryza sativa). International Journal of Pharma and Bio Sciences, 2(2): 1-8.

Prasad, B., J. Prasad and Prasad, R. 1995. Nutrient management for sustainable rice and wheat production in calcareous soil amended with green manures, organic manures and zinc. Fertilizer News, 40: 39-45.

Rahman, F., A.T.M.S. Hossain, P.K. Saha and Miah, M.A.M. 2009. Effect of integrated use of organic manures and chemical fertilizers on yield, nutrient uptake and nutrient balance in the bush bean - T. aus - T. aman cropping pattern. Bangladesh Journal of Agricultural Research, 34(1): 157-164.

Rai, R. N., Singh R. D., Gupta S. K., Veugopalan, K. Gupta R.K. and Rana P. (1990) continuous and alternate application of fertilizer and manures in rice-wheat system on a humid hilly soils of India. Biertage Zur Tropichen Land Wirtscaft and Veterinamedizin, 28:398399

Rokima, J. (1985) Influence of nutrient supply on production and nutrient use efficiency on some cropping sequences in calcareous soil. Ph. D. Thesis (Soil science), RAU, Pusa, Bihar.

Sharma, A.R. and Mitra, B.N. (1990). Responce of rice to rate and application of organic materials. J. Agric. Sci., 114: 349-352.

Sharma, A.R. and Mitra, B.N. (1991). Direct and residual effect of organic material and phosphorous fertilizer in rice based 
cropping system. Indian J. Agron., 36: 299-303

Santhy, P., Jayshree, S., Muthuvel, P. and Selvi, D. (1998) Long term fertilizer experiments status of $\mathrm{N}, \mathrm{P}$ and $\mathrm{K}$ fractions in soil. J. Indian Soci. Soil Sci., 46: 395-398.

Singh, R.P., S.V. Subiah and Pillai, K.G. 1994. Summary of rice-wheat cropping system trials being pursued by the DRRW. Workshop at Punjab
Agricultural University, Ludhiana, India (30th Aug. to 2nd September, 1994).

Tiwari, K.N. and Pathak, A.N. (1979) Fertl. News. 24: 39p (c.f. Yadav, D.S. and Kumar, Alok 1993. System based integrated nutrient management for suitable crop production in Utter Pradesh. Fertl. News. 38: 45-51).

USDA.2010. Grain: World Markets and Trade, July, 2010, www fas.usda.gov/ psd online pp 44- 51.

\section{How to cite this article:}

Sunil Kumar, Sanjay Tiwari, Birendra Kumar, B. K. Vimal, R. D. Ranjan and Azad, C. S. 2020. Residual Effect of Integrated Nutrient Management on Yield and Nutrients Uptake of Wheat under Rice-Wheat System. Int.J.Curr.Microbiol.App.Sci. 9(09): 701-711. doi: https://doi.org/10.20546/ijcmas.2020.909.089 